\title{
External Shocks and Business Cycle Fluctuations in Oil-exporting Small Open Economies: The Case of Nigeria
}

\section{Sunday Oladunni ${ }^{\dagger+\$}$}

This study employs a sign-restricted Bayesian structural vector autoregressive (BSVAR) model to analyse how global demand, oil price and the US monetary policy shocks impact the Nigerian business cycle. The objective is to uncover the dominant external drivers of the business cycle in Nigeria. Results show that global demand and oil price shocks are the principal foreign drivers of the Nigerian business cycle. The global demand shock elicits the strongest responses from output growth and inflation; while oil price shock impacts the terms-of-trade and interest rate the most. The historical contributions of the global demand and oil price shocks to the evolution of output growth are significant and comparable, while that of oil price shock to inflation and interest rate is dominant. Further sensitivity analysis of pre-crisis period of 2008/09 suggests that macroeconomic risk arising from global demand shock is systematic, owing to the comparable impact on output growth and similar interest rate response in the two estimations. Evidence suggests that the GFC may have contributed to the more volatile inflation response to global demand shock in our full sample estimation. Given the strong and pervasive impact of the global demand shock on output growth, Nigeria can manage its vulnerability by shrinking the size of oil exports in its terms-of-trade, while growing non-oil exports progressively through sustained economic diversification and viable industrialisation strategy.

Keywords: External Shocks, Sign Restrictions, Bayesian SVAR, Business Cycle Fluctuation

JEL Classifications: F44, E37, C11, E32

DOI: 10.33429/Cjas.10219.2/6

\subsection{Introduction}

The role played by external shocks in the evolution of countries business cycles is recognized in the literature (Calvo, Leiderman and Reinhart,

${ }^{+}$Monetary Policy Department, Central Bank of Nigeria, Abuja, soladunni@cbn.gov.ng.

$\$$ The views expressed in this paper, are purely those of the author, and do not represent the views of the Central Bank of Nigeria. 
1993; Canova, 2005; Mackowiak, 2007). However, empirical questions still abound in oil-exporting small open economies (SOEs) on the relative contributions of specific external shocks to the business cycle process. Each foreign shock affects countries in different ways, depending on the extent of each country's vulnerability, size of the shock and the active channels of transmission for the shock (Silva, 2012). A clear understanding of the strands of external shocks driving the business cycle is crucial for the formulation and implementation of appropriate macroeconomic policy responses. The knowledge of key business cycleperturbing external shocks is particularly of interest to policy makers in oil-exporting small open economies, in view of the important roles oil exports in those economies. This argument is buttressed by the submission of Cashin and Sosa (2013), that an accurate identification and evaluation of sources of foreign disturbances and the mechanisms for adjusting to them is important for understanding business cycles dynamics and for designing appropriate policies to manage them. In other words, the extent of a country's vulnerability to external shocks determine the choice, intensity and sequence of policy responses to such a shock.

Extant literature on Nigeria focuses overwhelmingly on the identification of individual foreign shocks, with huge concentration on oil price shock. For instance, Olomola and Adejumo (2006), Omisakin (2008), Umar and Kilishi (2010) and Ekong and Effiong (2015); amongst many others, zeroed in on oil price shock in their studies. The emphasis on oil-related shocks tend to obscure other potentially important external shocks to which the Nigerian economy may be susceptible. Thus, resulting in inaccurate inferences and inappropriate policy prescriptions. In order to address this, we adopt a unified approach achieved through block identification of three external shocks, namely: global demand, oil price and US monetary policy shocks. This modelling approach is particularly useful for disentangling the different external shock components affecting domestic business cycle movement. Through this approach, we can uncover the impact of each external shock and the corresponding relative contribution of each shock, over time, to the Nigerian business cycle.

This paper aims to investigate the relative contributions of the three external shocks in the evolution of the Nigerian business cycle using signrestricted Bayesian structural vector autoregressive (SVAR) modelling technique. To our knowledge, this is the first attempt to apply this methodology on the Nigerian data to analyse a subject that has received 
limited attention in the oil-exporting small open economy literature. The paper, therefore, represents an important addition to the applied macroeconomic literature in Nigeria and the wider oil-exporting developing and emerging economies. The sign restriction identification procedure derives from Olayeni (2009), Adebiyi and Mordi (2012) and Allegret and Benkhodja (2015), in addition to the global macroeconomic literature in line with Mumtaz and Surico (2009) and Kilian and Lewis (2011).

The results show that global demand shocks tend to impact domestic output growth positively for a long time. Similarly, domestic inflation exhibits high sensitivity to the global demand shock, while monetary policy tightens over longer horizon in response to the global demand shock-induced inflationary pressure. The sharp but short-lived response of terms-of-trade to the global demand shock stems directly from the positive response of oil price to the same shock, given the close link between the two variables in Nigeria. It is apparent from our results, that any shock that moves the oil price upward will elicit similar effect on the terms-of-trade, as oil exports constitute a major component of the termsof-trade. There is a delayed positive domestic inflation response to the US monetary policy shock, suggesting that monetary tightening in the US can elicits inflationary consequences in SOEs. This can be attributed to the effects of capital reversal arising from increased returns on financial assets in the US and the consequent flight to safety and quality. The lag in inflation response, however, may reflect investors cautious attitude or potential temporary constraints to capital mobility.

In addition, the US monetary policy shock exerts a moderate and negative effect on the domestic output growth in our model; indicating that monetary policy actions in the rest of the world do matter for macroeconomic stabilisation in Nigeria. The oil price shock does not cause inflation on impact; rather, it contributes to inflationary momentum over time. This result captures how oil boom often results to immediate improvement in external reserves position and exchange rate appreciation. However, with time, the boom induces decline in competitiveness, higher demand for imported goods and excess domestic liquidity which often fuel exchange rate and inflationary pressures, that may compel the central bank to tighten policy stance. Overall, the global demand and oil price shocks are revealed to exert significant influence on domestic output growth and the most discernible effect on inflation compared to the US monetary policy shock. The result shows that the global demand shock is the prime 
mover of business cycle fluctuations in Nigeria. Our robustness exercise in which the model was re-estimated for the pre-GFC period show that, whereas global demand shock had similar effects on domestic output growth and interest rate, its effects on inflation volatility moderated significantly in the pre-crisis period. This indicates that the global financial crisis (GFC) amplified inflation volatility given a global demand shock.

Section 2 summarises stylized facts on the variables and section 3 presents a survey of the literature. Section 4 explores the methodology while section 5 treats the model, identification strategy and estimation. Section 6 presents and discusses the results while section 7 concludes the paper.

\subsection{Stylized Facts}

To provide some preliminary insights on relevant sets of external and domestic variables in the paper, we show three charts which pair each external variable with two most important domestic business cycle variables, as well as the descriptive statistics of the data. Figure 1 below, shows movement in the quarterly world output growth, domestic output growth and domestic inflation rates between 2001Q1 and 2016Q1.

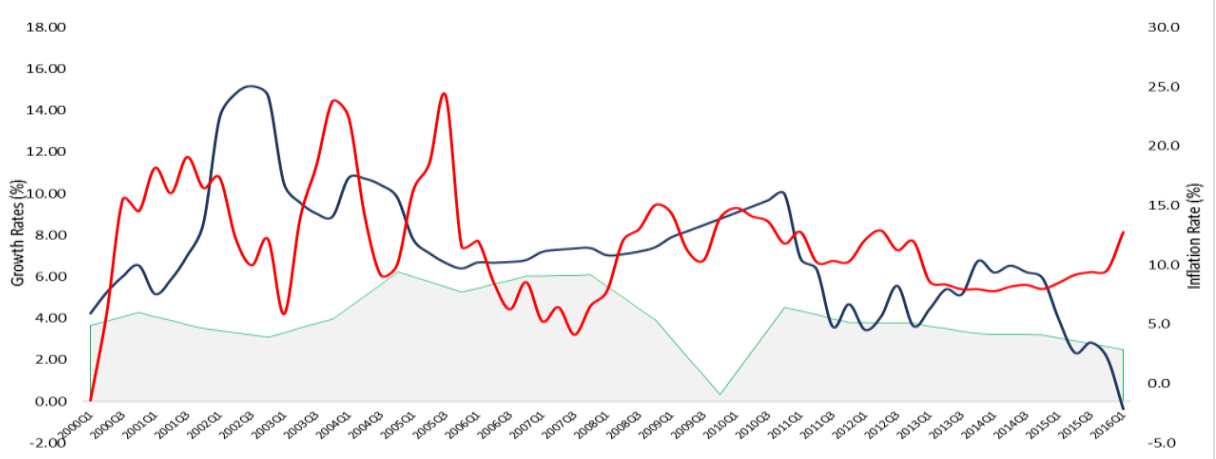

Figure 1: World Output Growth, Domestic Growth and Inflation Rates

Over the period, world output growth had been positive and stable around an average of 3.0 percent. The worst performance for global growth was experienced late 2009 at 0.34 percent. This is due to the impact of the global financial crisis of 2008/09 which resulted from a world-wide credit crunch. It is observed that, the GFC-induced low global growth did not affect Nigeria's growth performance immediately. The effect, however, became manifest after a three-quarter lag; suggesting that spill-over effect may be stronger than contagion effect in Nigeria. This may also justify the 
possibility of the trade channel being stronger than the financial channel in Nigeria. Domestic inflation rate is high and mostly in the double-digit range over the period. Domestic output and inflation are shown to move in nearly opposite direction. A classic example of this is between 2015Q1 and 2016Q1 when domestic output growth and inflation moved in sharply opposite directions; with output decelerating into negative territory as inflation skyrocketed. The grave macroeconomic situation has remained daunting for policymakers in many oil-exporting emerging economies.

Figure 2 show trends in oil price, domestic growth and inflation between 2001Q1 and 2016Q1. The chart suggest that oil price and inflation are more volatile and tend to co-move on the average.

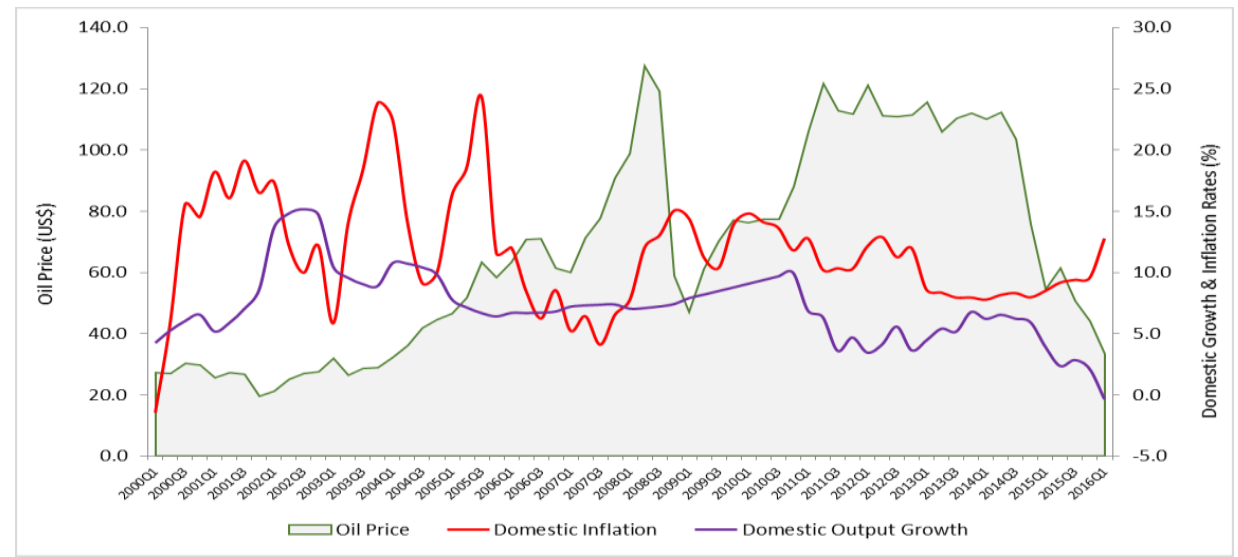

Figure 2: Oil Price, Domestic Growth and Inflation Rates

Domestic output growth assumes a unique and less volatile trend; and does not share strong co-movement with the oil price. However, both oil price and domestic growth exhibit strong co-movement between 2014Q3 and 2016Q1. The observed co-movement between oil price and domestic growth is asymmetric; as it is more visible when oil price is on a downward path. This trend, when linked with the observed rising inflation during the period, tend to suggest that fall in oil price is both recessionary and inflationary in Nigeria.

Figure 3 below, shows movement in the US federal funds rate, domestic output growth and inflation. Overall, this chart does not indicate significant patterns between federal funds rate and domestic variables. However, there is a slight indication that Nigeria's output performance is somewhat improved as foreign interest rate falls. This observation is buttressed by the recent trend whereby low interest rate environment in developed economies encourages capital flows into emerging market economies with high interest rates. An emerging economy with high 
inflow of foreign capital can leverage such inflows to achieve economic growth.

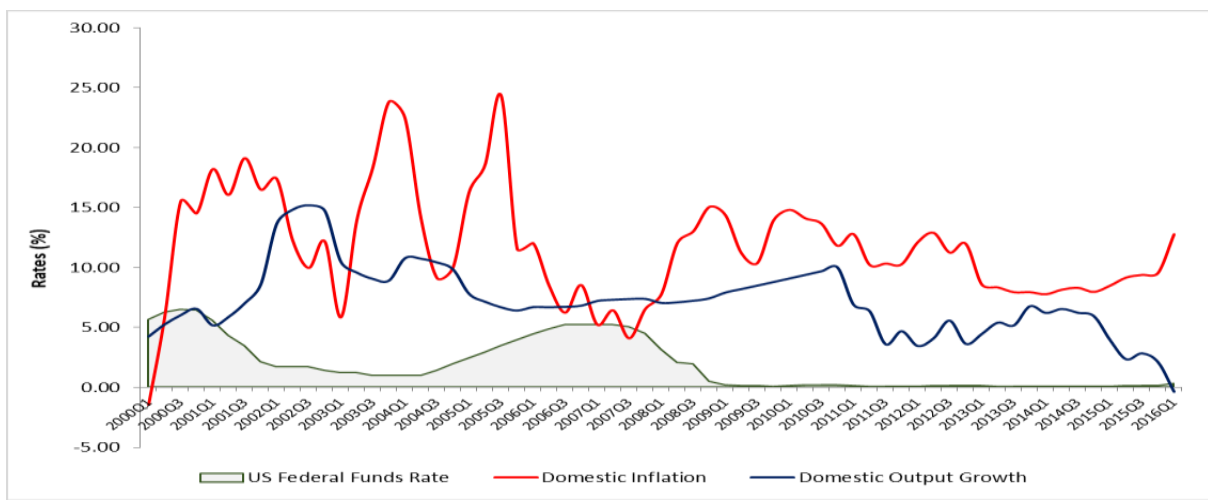

Figure 3: US Federal Funds, Domestic Inflation and Growth Rates

Table 1 shows the descriptive statistics of the data. GOG is global output growth, FFR is US federal funds rate, OPG is oil price growth (Bonny Light Oil price changes), DOG is domestic output growth, INF is domestic inflation, TOT is terms-of-trade and DIR is domestic interest rate.

Table 1: Descriptive Statistics

\begin{tabular}{lccccccc}
\hline & GOG & FFR & OPG & DOG & INF & TOT & DIR \\
\hline \hline Mean & 3.509 & 4.358 & 1.159 & 4.605 & 21.03 & 0.012 & 11.97 \\
Median & 3.476 & 4.838 & 1.081 & 5.003 & 13.28 & -0.489 & 11.72 \\
Maximum & 6.226 & 14.51 & 65.82 & 15.18 & 89.56 & 33.89 & 27 \\
Minimum & 0.338 & 0.073 & -50.56 & -8.061 & -4.976 & -31.66 & 4.63 \\
Std. Dev. & 1.281 & 3.252 & 14.87 & 4.48 & 19.66 & 8.233 & 4.306 \\
Skewness & 0.052 & 0.292 & 0.171 & -0.332 & 1.43 & 0.393 & 0.979 \\
Kurtosis & 2.761 & 2.404 & 5.943 & 3.482 & 4.195 & 7.124 & 4.103 \\
Jarq.-Bera & 0.384 & 3.953 & 49.75 & 3.824 & 54.48 & 99.91 & 28.64 \\
Probability & 0.825 & 0.138 & 0 & 0.147 & 0 & 0 & 0 \\
Sum & 477.2 & 592.7 & 157.7 & 626 & 2860 & 1.705 & 1628 \\
SS. Dev. & 221.5 & 1428 & 29877 & 2709 & 52206 & 9151 & 2503 \\
\hline
\end{tabular}

The table indicates that the distribution of four out of the seven variables satisfy the normality assumption while three did not. Compared to foreign variables, the average values and the volatility of domestic variables such as DOG and DIR are much higher than their foreign counterparts (i.e. GOG and DIR, respectively). Oil price growth and inflation exhibit the highest level of volatility in the dataset, a development that aligns with the general characteristics of macroeconomic variables in oil-exporting small open emerging and developing economies. 


\subsection{Literature Review}

The literature provides evidence on the effects of external shocks on oil and non-oil-exporting small open economies. While many studies find external shocks to be the major drivers of business cycle fluctuations, others assign a less significant role to external shocks in the evolution business cycle variables. In the case of Australia, Dungey (2002), following results from a SVAR estimation, attributes only 32 percent of the variations in output forecast errors over a twelve-month horizon to external shocks and show that domestic demand shocks are dominant. Contrary to Dungey (2002), given results from an estimated New Keynesian DSGE model, Nimark (2007) submits that external shocks explain more than half of the variance in output while domestic demand shocks account for just 8.0 per cent.

Sariola (2015) investigates the structural shocks driving the Swedish business cycle, using a sign-restricted SVAR, identifies four shocks based on theoretical underpinnings from Riksbank's Ramses II DSGE model by Adolfson, Laseen, Christiano, Trabandt and Walentin (2013). The results indicate that nearly half of the volatility in the Swedish output is accounted for by productivity and external demand shocks; while the contribution of domestic demand shock to output volatility is negligible. The notion that external shocks do impact considerably on emerging and developing economies was further strengthened by Calvo, Leiderman and Reinhart (1993), who applied a SVAR model and finds that foreign shocks account for a significant share of the variance in the real exchange rate in the period 1988 - 1991 in Latin America. Broda and Tille (2003) in a study covering seventy-five developing countries across Asia, Africa, Latin America and Eastern Europe, investigated how terms-of-trade can affect a country's real income, price level and exchange rate, using the VAR methodology. They find that a large proportion of the output volatilities in developing countries can be attributed to changes in the terms-of-trade.

Huang and Guo (2006) identified a global supply shock in a SVAR model using data over the period 1970 - 2002 and finds external innovations to be significant. $\mathrm{Ng}$ (2002), in a study of five emerging countries in South Eastern Asia, spanning 1970 - 1995, identified one external shock and two domestic shocks using a SVAR. The study indicates that the response of domestic variables to external shocks across these countries is strong, thus, providing an empirical justification for the establishment of a monetary union in the region. Similarly, Genberg (2005) estimated a VAR 
model to investigate the effects of external shocks on East Asian economies and finds that foreign shocks from the US, rather than China, mainly account for the inflation dynamics in the six 'Asian Tigers' economies of Hong Kong, Thailand, Singapore, Korea, Taiwan and the Philippines. In a related study on emerging market countries over the period 1986M1 - 2000M12, Mackowiak (2007) used world commodity prices, the US Federal funds rate, the US aggregate price level, the US money stock and the US aggregate output as external shocks. Results from the study suggest that all external shocks apart from the US monetary policy shock affect domestic variables significantly in these economies. In addition, the study underscores the tendency for external shocks to be persistent, as they are shown to contribute more to fluctuations in emerging economies' domestic variables at longer forecast horizons.

Sato, Zhang and McAleer (2011) examined the contributions of external shocks to fluctuations in East Asian countries' business cycles, with a SVAR model that applied block exogeneity to achieve identification in line with the small open economy assumptions. Estimation is conducted for three sub-samples: 1978Q1-1987Q4; 1988Q1-1996Q4; and 1999Q12007Q4 to detect dynamics inherent in each episode of external shocks, as well as the business cycle dynamics of East Asian countries. Findings from the study indicate that external shocks from the US and Japanese were prominent in East Asian countries prior to the GFC. After the crisis, however, while the US shocks still dominated as the main source of fluctuations in rest of East Asia, China's main vulnerability had been to Japanese shocks. Utlaut and Van Roye (2010) analysed the effects of external shocks on Asia's emerging economies through Bayesian VAR estimation and showed that nearly half of the drivers of emerging Asia's real GDP growth rate is attributable to external innovations. They simulated a double dip situation in the global economy, with a subdued growth path in China based on conditional forecasts, it was discovered that the global economic growth trajectory dictates significantly emerging Asia's economic outlook and not the Chinese business cycle fluctuations.

Silva (2012) examined the role domestic and external shocks play in driving business cycles in Mexico and Brazil. A non-recursive contemporaneous and block recursive restrictions were imposed and the model was estimated using Bayesian procedure. Results show that the US output shock, compared to the US monetary policy shock, exerts greater influence on domestic output volatility. The result also shows that, while 
commodity price shocks account for nearly 18.0 per cent of the output volatility in a 2-year horizon in Brazil, it accounts for about 20 percent in Mexico in the same time horizon. Houssa, Mohimont and Otrok (2015) used a mix of sign and recursive restrictions in a Bayesian VAR modelling framework to examine the role international and domestic shocks play in shaping the business cycle processes in Ghana and South Africa. Their results indicate that world productivity and credit shocks dominate more in South Africa than in Ghana, while commodity shocks impact immensely on both countries business cycles. Global credit market shocks had no effect on Ghana while productivity shock did, suggesting that Ghana's integration with the global economy works more via trade channels and less via financial channels. Their findings underscore the need to recognize the role of the primary goods sector for policy purposes in commodity-exporting countries.

Rafiq (2011) assumes a small open economy condition to investigate sources of economic fluctuations in oil-exporting countries and their implications for the choice of exchange rate regime using a sign-restricted SVAR. Shocks were identified based on "textbook economic theory" and the results indicate that the terms-of-trade shocks impact the exchange rate and domestic price movements more than domestic shocks in oilexporting emerging market economies. A robustness exercise in which the terms-of-trade variable is replaced with oil price yielded similar results, except that oil price shock is shown to exert greater influence on the exchange rate. In addition, results of the robustness exercise also suggest that most of the volatility in the terms-of-trade in emerging market oilexporting economies are due to oil price changes.

Olomola and Adejumo (2006) examined the effects of oil price shocks on inflation, output, the real exchange rate and money supply in Nigeria using standard VAR and finds that oil price shocks' direct effects on inflation and output are muted. Whereas, inflation is influenced by output and the real exchange rate shocks, oil price shocks impact significantly on the real exchange rate. The results also reveal that oil price shocks pass-through in Nigeria operate via the real exchange rate and money supply, respectively. Philip and Akintoye (2006), Christopher and Benedikt (2006) and Omisakin (2008) are unanimous in their conclusions that oil price shock has no significant effect on domestic variables. However, Umar and Kilishi (2010) using a VAR methodology finds that oil price has significant effects on real output, unemployment and money supply; while the effect is not found to be significant for the consumer price index. 
Similarly, Akpan (2009) reports that exchange rate, inflation and output exhibit significant sensitivity to oil price movement in Nigeria. Alege (2015) characterize the Nigerian business cycle using a DSGE model in the spirits of Nason and Cogley (1994) and Schorfheide (2000); extended to incorporate the export sector with a view to reflecting the transmission mechanism of terms-of-trade. Results from the study show that the Nigerian business cycle is driven by both real and nominal shocks.

Extant literature suggests that the effects of external shocks as observed with small open economies in Asia, Latin America, Middle East and Africa are not the same with the G-7 countries. For instance, Kim (2001) finds that the spill-over effect of US monetary policy shocks to the G-7 ${ }^{3}$ countries is not significant. This result provides some degree of corroboration for subsequent findings by Mackowiak (2007), which suggests that the emerging market economies tend to exhibit greater susceptibility to external shocks compared to advanced economies. More recently, Huh and Kwon (2015) estimate a Bayesian SVAR model of the real exchange rate, output and trade balance for the G-7 with a set of sign restrictions derived from Clarida and Gali (1994)'s stochastic rational expectations open-economy model with sticky prices. They extend the model by incorporating trade balance and identifying supply shocks using the implied long-run restrictions of the output-neutrality condition. Their results show that nominal shocks tend to induce real exchange rate depreciation; leading to improvements in the trade balance in the long run across the G-7 economies.

\subsection{Methodology, Model and Estimation}

\subsection{Methodology}

Generally, VAR models are known to forecast and describe dependencies among variables well. Since Sims (1980) popularization of this class of models, they have become increasingly useful for applied macroeconomic and policy analysis (Christiano, Eichenbaum and Evans, 1998; Canova, 2005 and Lütkepohl, 2012).

$\operatorname{A~} \operatorname{VAR}(p)$ process is of the form:

$$
y_{t}=A_{i} y_{t-i}+e_{t}
$$

${ }^{3}$ The G-7 is the group of seven leading advanced economies in the world including the U.S., Canada, France, Germany, Italy, Japan and the U.K. 
where $y_{t}$ is $(N x 1)$ vector of endogenous variables in the model; $A_{i}$ is $(N x N)$ matrix of coefficients, for $i=1,2, \ldots, p$; and, $e_{t}$ represents $(N x 1)$ vector of unobservable white noise processes with $E\left(e_{t}\right)=0$, constant and positive-definite covariance matrix $E\left(e_{t} e_{t}^{\prime}\right)=\operatorname{cov}\left(e_{t}\right)=\Omega_{e}$. The errors $\left(e_{t}\right)$ have zero autocorrelation but may be correlated across equations. This possibility of cross equations correlation tends to undermine the plausibility of extracting valid economic intuitions from the reduced-form VAR models. Typical VAR models are purely statistical. Therefore, to make meaningful economic and policy inferences from any VAR estimates, plausible economic structures are normally imposed on the unrestricted VAR system. The structural equivalent of (1) is of the form:

$B_{0} y_{t}=B_{i} y_{t-i}+\epsilon_{t}$

where matrix $B_{0}$ is the contemporaneous impact matrix, which summarizes the instantaneous interactions among the variables; $B_{\mathrm{i}}$ is $(N x N)$ matrix of coefficients of the model dynamics. The first feature which distinguishes the structural VAR from the unrestricted VAR is the addition of the impact matrix $B_{0}$, and the second, is the replacement of the reduced-form errors or residuals, $e_{t}$ by an $(N x 1)$ vector of structural shocks or unobservable zero mean white noise processes, $\epsilon_{t}$. This property ensures that $\epsilon_{t}$ are serially uncorrelated and independent of each other such that the variance covariance matrix $\Omega_{\epsilon}$ is normalized to $I$.

To ensure that shocks $\epsilon_{t}$ are truly structural and different from the reduced-form residuals, $e_{t}$, they must be orthogonalized. Identification may be achieved through exclusion restrictions, proportionality restrictions or other equality restrictions (Lütkepohl, 2012; Kilian, 2013; Bjornland and Thorsrud, 2015). Using sign restriction, Faust (1998), Canova and De Nicolo (2002) and Uhlig (2005) achieved identification by restricting the sign (and/or shape) of structural responses. They identify a set of impulse responses which agrees with theory-based sign expectations. Unlike the recursive and non-recursive techniques which are subject to criticisms largely due to the scepticism about the validity of the identifying restrictions employed in them, the sign-restricted SVAR has a strong theoretical focus, given that applicable a priori expectations are usually extracted from the outputs of relevant theoretical models. Canova (2007), Mountford and Uhlig (2009) and Pappa (2009) applied sign restrictions to analyse fiscal shocks, Dedola and Neri (2007) used it to study the effects of technology shocks, Canova and De Nicolo (2002) and 
Scholl and Uhlig (2008) for open economy shocks and Kilian and Murphy (2012), Baumeister and Peersman (2013) considered oil markets applications, while Fujita (2011) modelled labour market dynamics with it. The procedure for implementing sign restrictions are as in FernandezVillaverde and Rubio-Ramirez (2010), Kilian (2013) and Sariola (2015).

\subsection{Model}

We identify a block $\epsilon_{t}^{f}$ of three external shocks assumed to drive both foreign and domestic business cycle variables. Vector $y_{t}$ in (2) is constructed as follows:

$$
\left[\begin{array}{c}
f_{t} \\
d_{t}
\end{array}\right]=\alpha x_{t}+\sum_{i=1}^{\mathrm{p}} A_{i}\left[\begin{array}{c}
f_{t-i} \\
d_{t-i}
\end{array}\right]+B_{0}^{-1}\left[\begin{array}{c}
\epsilon_{t}^{f} \\
\epsilon_{t}^{d}
\end{array}\right]
$$

where $y_{t}=\left[\begin{array}{l}f_{t} \\ d_{t}\end{array}\right] ; f_{t}$ and $d_{t}$ represent the vectors of foreign and domestic variables, respectively; $x_{t}$ is the vector of exogenous variables and $B_{0}^{-1}$ is the impact matrix of contemporaneous effects of the mutually uncorrelated foreign shocks vector in the system. The modelling framework for the small open economy assumption requires that matrix $A_{i}$ is the lower triangular matrix which does not allow the lagged values of domestic variables to affect those in the foreign block. The $B_{0}^{-1}$ matrix also, in line with Karagedikli and Price (2012) would be restricted to a lower triangular matrix in order to capture small open economy features contemporaneously.

$$
\left[\begin{array}{c}
\Delta y_{t}^{w} \\
i_{t}^{u s} \\
\triangle o_{t}^{p} \\
i_{t}^{d} \\
\triangle y_{t}^{d} \\
\pi_{t}^{d} \\
\triangle \kappa_{t}
\end{array}\right]=A_{1}\left[\begin{array}{c}
\Delta y_{t-1}^{w} \\
i_{t-1}^{u s} \\
\triangle o_{t-1}^{p} \\
i_{t-1}^{d} \\
\triangle y_{t-1}^{d} \\
\pi_{t-1}^{d} \\
\triangle \kappa_{t-1}^{d}
\end{array}\right]+A_{2}\left[\begin{array}{c}
\Delta y_{t-2}^{w} \\
i_{t-2}^{u s} \\
\triangle o_{t-2}^{p} \\
i_{t-2}^{d} \\
\Delta y_{t-2}^{d} \\
\pi_{t-2}^{d} \\
\triangle \kappa_{t-2}
\end{array}\right]+B_{0}^{-1}\left[\begin{array}{c}
\epsilon_{t}^{\Delta y^{w}} \\
\epsilon_{t}^{i^{u s}} \\
\epsilon_{t}^{\Delta o^{p}} \\
\epsilon_{t}^{i^{d}} \\
\epsilon_{t}^{\Delta y^{d}} \\
\epsilon_{t}^{\pi^{d}} \\
\epsilon_{t}^{\Delta \kappa}
\end{array}\right]
$$

Sign restrictions are imposed on the shock matrix $B_{0}^{-1}$ to identify the model. The selection of model variables reflects the tradition in the literature ${ }^{4}$ which often accord important roles to global demand, US monetary policy stance and commodity prices in shaping macroeconomic

\footnotetext{
${ }^{4}$ Please see Canova (2005); Jaaskela and Smith (2011) and Silva (2012)
} 
trends in commodity-endowed small open economies. Fluctuations in inflation, output, interest rate and terms-of-trade dynamics are often used to approximate the business cycle process.

$$
\begin{aligned}
& f_{t}=\left[\begin{array}{lll}
\Delta y_{t}^{w} & i_{t}^{u s} & \Delta o_{t}^{p}
\end{array}\right]^{\prime} \\
& d_{t}=\left[\begin{array}{llll}
i_{t}^{d} & \triangle y_{t}^{d} & \pi_{t}^{d} & \Delta \kappa_{t}
\end{array}\right]^{\prime}
\end{aligned}
$$

The foreign block $f_{t}$ includes the global output growth $\Delta y_{t}^{w}$ (GOG), the US federal funds rate $i_{t}^{u s}$ (FFR) and oil price growth $\triangle o_{t}^{p}$ (OPG); while the domestic block $d_{t}$ includes the domestic interest rate $i_{t}^{d}$ (DIR), domestic output growth $\triangle y_{t}^{d}$ (DOG), domestic inflation rate $\pi_{t}^{d}$ (INF) and changes in the terms-of-trade $\Delta \kappa_{t}$ (TOT). Foreign shocks in $\epsilon_{t}^{f}$ are assumed to affect variables in both $f_{t}$ and $d_{t}$; and $f_{t}$ variables are determined by their own lags and foreign shocks; while $\epsilon_{t}^{d}$ shocks are not activated. With reference to Nigeria, oil price shock is largely exogenous, given that factors determining the evolution of crude oil price are predominantly international. The US monetary policy innovations have effects on the Nigerian financial market due to globalization and capital flow dynamics. In the same vein, the state of the global economy can influence Nigeria's economy given her status as a notable exporter of crude oil. The vector of foreign shocks impacting the Nigerian economy is shown as follows:

$\epsilon_{t}^{f}=\left[\begin{array}{lll}\epsilon_{t}^{\Delta y^{w}} & \epsilon_{t}^{i u s} & \epsilon_{t}^{\Delta o^{p}}\end{array}\right]^{\prime}$

where $\epsilon_{t}^{\Delta y^{w}}$ is the global demand shock (GDS), which represents any surprise event that increases world output growth; $\epsilon_{t}^{i \text { us }}$ is the US monetary policy shock (USMPS), which is an indicator of US contractionary monetary shock while $\epsilon_{t}^{\triangle o^{p}}$ is the oil price shock (OPS), which is summarised by all exogenous events that causes oil price changes in the upward direction. The domestic block of structural shocks $\epsilon_{t}^{d}: \epsilon_{t}^{i^{d}}, \epsilon_{t}^{\Delta y^{d}}, \epsilon_{t}^{\pi^{d}}, \epsilon_{t}^{\Delta \kappa}$ is muted as it is not identified in our model.

We identify specific external shocks based on the direct intuitions from three relevant DSGE models, developed to capture the peculiar structures of Nigeria and Algeria, both prominent African oil exporters. These models include Olayeni (2009), Adebiyi and Mordi (2012), and Allegret and Benkhodja (2015). We assign restrictions as shown in table 2 below. We identified three external shocks, namely: global demand shock $\left(\epsilon_{t}^{\Delta y^{w}}\right)$, US monetary policy shock $\left(\epsilon_{t}^{i u s}\right)$ and oil price shock $\left(\epsilon_{t}^{\Delta o^{p}}\right)$. The 
shocks are propagated through both foreign and domestic variables. In the table, a positive sign (+) indicates that the response of a variable to a shock is restricted to be positive, whereas, a negative sign (-) means that the response of a variable to a shock is set to negative. The symbol (?) indicate no restrictions are imposed and that we are agnostic about the sign that a variable will assume in response to a given shock. This approach becomes more appealing where the literature is inconclusive on the definite pattern of impact between a shock and a variable. The identification scheme is as summarized in table 2 below.

Table 2: Identification Scheme

\begin{tabular}{cccccccc}
\hline \multirow{2}{*}{ Shocks/Variables } & GOG & FFR & OPG & DIR & DOG & DINF & TOT \\
& & & & & & & \\
\hline \hline GDS & $(+)$ & $(+)$ & $(+)$ & $(+)$ & $(+)$ & $(+)$ & $(+)$ \\
USMPS & $(-)$ & $(+)$ & $(?)$ & $(+)$ & $(-)$ & $(?)$ & $(?)$ \\
OPS & $(-)$ & $(-)$ & $(+)$ & $(+)$ & $(+)$ & $(?)$ & $(+)$ \\
\hline
\end{tabular}

GOG is global output growth; FFR is federal funds rate; OPG is oil price growth, DIR is domestic interest rate; DOG is domestic output growth; DINF is domestic inflation and TOT is terms-of-trade. GDS is global demand shock; USMPS is US monetary policy shock and OPS is oil price shock. A positive global demand shock is assumed to elicit an increase in all global and domestic macroeconomic aggregates (Mumtaz and Surico, 2009). Shock to the US monetary policy is expected to propel a rise in the US federal funds rate and in the domestic interest rate. An emerging market economy typically responds to a US monetary policy shock with an increase in the domestic monetary policy rate in favour of international competitiveness required to sustain or attract capital inflows into the country. We are however agnostic about how oil price, domestic inflation and terms-of-trade responds to a U.S. monetary policy shock. Oil price shock is believed to impact negatively on both global output growth and the Federal funds rate. This is in line with Carlstrom and Fuerst (2006), Kilian and Lewis (2011) and Inoue and Kilian (2013) who argue that oil price shock causes an increase in the price of oil and induces global real activity to fall on impact.

On the US Fed's response to an oil price shock, Bernanke, Gertler, Watson, Sims and Friedman (1997) submit that the Fed responds to oil price shocks with restrictive monetary policy in order to check inflation. Kilian and Lewis (2011), however, questioned this proposition on three 
main grounds. First, they argue that the Fed cares as much about output and employment stabilization as it cares about containing inflation; and that the Fed was overly concerned with the output objective during the 1970s. Second, given that the demand side of oil price shock transmission channel (which may be further complicated by higher precautionary savings) is stronger than the cost-induced supply side channel, an exogenous oil price shock will be recessionary or deflationary and thus, there is no basis to pursue a restrictive monetary policy in response to oil price shock. Third, since oil price shocks are the symptoms of a cause, policy responses, therefore, should target the underlying demand and supply shocks that drive oil price. The effect oil price shock would have on the economy depends on the source of the shock (Kilian, 2008). For instance, if an oil price shock is demand driven, it may not result in decline in output after all. The argument by Kilian and Lewis (2011) corroborate findings by Hamilton and Herrera (2004), which show that Bernanke et al. (1997)'s conclusion about the Fed's restrictive monetary policy response to oil price shock was mainly influenced by the small lag length applied in their model. Therefore, using a larger sample and higher lag length to capture the dynamics in the monthly data, they found that monetary policy in the US was indeed loose in response to oil price shocks.

Based on Allegret and Benkhodja (2015), domestic output growth responds positively to oil price shocks. Although, our reference theoretical model suggests a positive inflation response to oil price innovations, we chose to remain agnostic about this interaction. Oil price shock and domestic interest rate are observed to be positively correlated in keeping with the restrictive monetary policy stance targeting inflationary pressures due to oil boom in the economy.

$\left[\begin{array}{c}e_{t}^{\Delta y^{w}} \\ e_{t}^{i^{u s}} \\ e_{t}^{\Delta o^{p}} \\ e_{t}^{i^{d}} \\ e_{t}^{\Delta y^{d}} \\ e_{t}^{\pi^{d}} \\ e_{t}^{\Delta \kappa}\end{array}\right]=\left[\begin{array}{ccccccc}+ & - & - & 0 & 0 & 0 & 0 \\ + & + & - & 0 & 0 & 0 & 0 \\ + & ? & + & 0 & 0 & 0 & 0 \\ + & + & + & 0 & 0 & 0 & 0 \\ + & - & + & 0 & 0 & 0 & 0 \\ + & ? & ? & 0 & 0 & 0 & 0 \\ + & ? & + & 0 & 0 & 0 & 0\end{array}\right] *\left[\begin{array}{c}\epsilon_{t}^{\text {Global Demand }} \\ \epsilon_{t}^{\text {US Monetary Policy }} \\ \epsilon_{t}^{\text {Oil Price }} \\ \epsilon_{t}^{\text {Domestic Monetary Policy }} \\ \epsilon_{t}^{\text {Domestic Demand }} \\ \epsilon_{t}^{\text {Domestic Supply }} \\ \\ \\ \epsilon_{t}^{\text {Trade }}\end{array}\right]$

As shown in equation 12, the sub-block of domestic shocks is inactive, indicating that domestic shocks are not allowed to impact the system of 
equations for foreign and domestic variables. Only foreign shocks are active, and they impact all the equations or variables in the system.

\subsection{Estimation}

To estimate the specified SVAR model, we apply the Bayesian technique on a seven-variable quarterly dataset over the period 1982Q2 - $2016 \mathrm{Q} 1$. Our external block variables include global output growth rate, US federal funds rate and oil price. These variables are important in our model set up, as they summarize the main characteristics of the international business cycle dynamics which have implications for both global and domestic economies. The domestic block contains variables capturing domestic business cycle fluctuations. They include output growth rate, inflation rate, interest rate and terms-of-trade. Data on global output growth and US federal funds rate are from World Bank and the Fed data bases, respectively; while terms-of-trade data is from FRED database of St. Louis Federal Reserve System, US. The growth rate of domestic output is sourced from the Nigerian National Bureau of Statistics (NBS), while oil price series, inflation and 3-month deposit interest rate are sourced from the Statistical Bulletin of the Central Bank of Nigeria. All data series are in logarithmic form thus, making it possible to compare results associated with different variables more credibly. Diagnostic tests performed on the data show that the series do not have unit root, the VAR system is stable and the optimal lag length for model estimation is 2 based on four different information criteria.

The Bayesian technique is often preferred when the sample is short and the number of variables in the VAR system is relatively large. In a large VAR model with small sample, the likelihood function does not behave well. Also, there is a problem of over-fitting arising from overparametrization, which tend to undermine the reliability of the estimates. However, in a Bayesian setting, prior information is used to compress models with huge coefficients on distant lags or explosive dynamics (Silva, 2012). We employ a prior that assumes the Normal-Wishart structure for the parameters of the reduced-form to generate a posterior of the same form, based on the identifying restrictions. 


\subsection{Analysis of Results}

\subsection{External Shocks and Domestic Business Cycle - Baseline Model}

Each of the shocks elicit a set of impulse responses contained within the dotted lines which indicates the upper and lower bands of the identified set, while the solid line is the median impulse response for each set. In the baseline model, we conducted estimation using the full sample data covering the period 1982Q2 - 2016Q1. The data range include both preand post-financial crisis period.

\subsubsection{Global Demand Shock}

The effects of external shocks on the movement of key domestic business cycle variables can be inferred from their dynamic responses to foreign innovations. As shown in figure 4 below, a unit shock to the global demand resulted in significant increase in the global output growth and the tightening of the US monetary policy. The stance of the US monetary policy tended to mirror the global momentum of growth as both increased slightly from the initial response and eventually returned to steady state after the twentieth quarter. The result suggests that the Fed considers the performance of the global economy in its monetary policy decisions. Similarly, the global demand shock elicits a sharp increase in the oil price growth and a milder increase in the terms-of-trade. However, these responses were short-lived as oil price growth and changes in terms-oftrade waned barely after the second quarter and became fully dissipated by the seventh quarter.
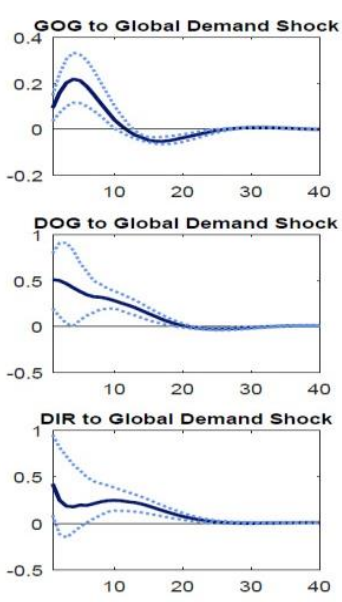
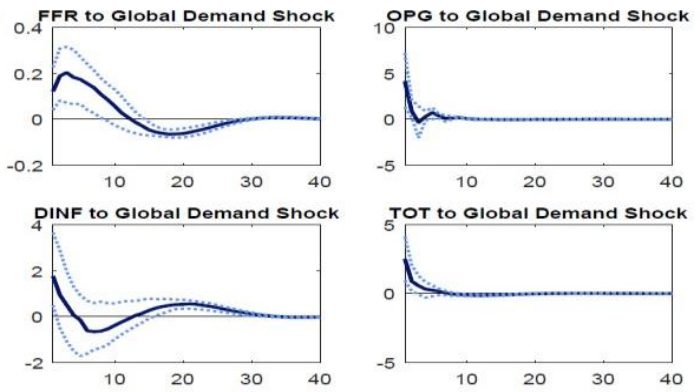

Figure 4: Impulse Responses to the Global Demand Shock 
The result reflects the volatile nature of the oil price and the associated revenue vulnerability for an oil exporter. The global demand shock is associated with a marked response from domestic output growth. This is the largest output growth response to any shock in our model. In the same vein, the response of domestic inflation to global demand shock is revealed to be remarkably high and volatile. The response of domestic interest rate was initially aggressive but became subsequently moderated and persistent until the twenty fifth quarter.

\subsubsection{US Monetary Policy Shock}

The dampening effect of US monetary policy shock on the global output growth is somewhat significant on impact. As seen in figure 5, the decline in the global output growth is most intense in the fourth quarter before returning to steady state in the fifteenth quarter. This response underscores the global counter-cyclical implication of tightening of monetary policy in the US, in order to reign in on the inflationary pressures associated with increased worldwide economic momentum. Given that we are agnostic about the response of oil price to a US monetary policy shock, the response is found to be positive and significant but unsteady as it jumped to negative territory in the third quarter and rebounded in the sixth quarter before returning to steady state in the eighth quarter. This oil price developments indicate the uncertainty surrounding the duration of the effect of the US monetary policy surprises on oil price growth. On impact, the US monetary policy shock had no effect on the terms-of-trade. The subdued impact became manifest and peaked near zero in the third quarter and then gradually returned to steady state in the eight quarter. The positive response of domestic inflation to the US monetary policy shock happens after a quarter delay. It peaks moderately in the fifth quarter before dissipating eventually in the thirteenth quarter. 

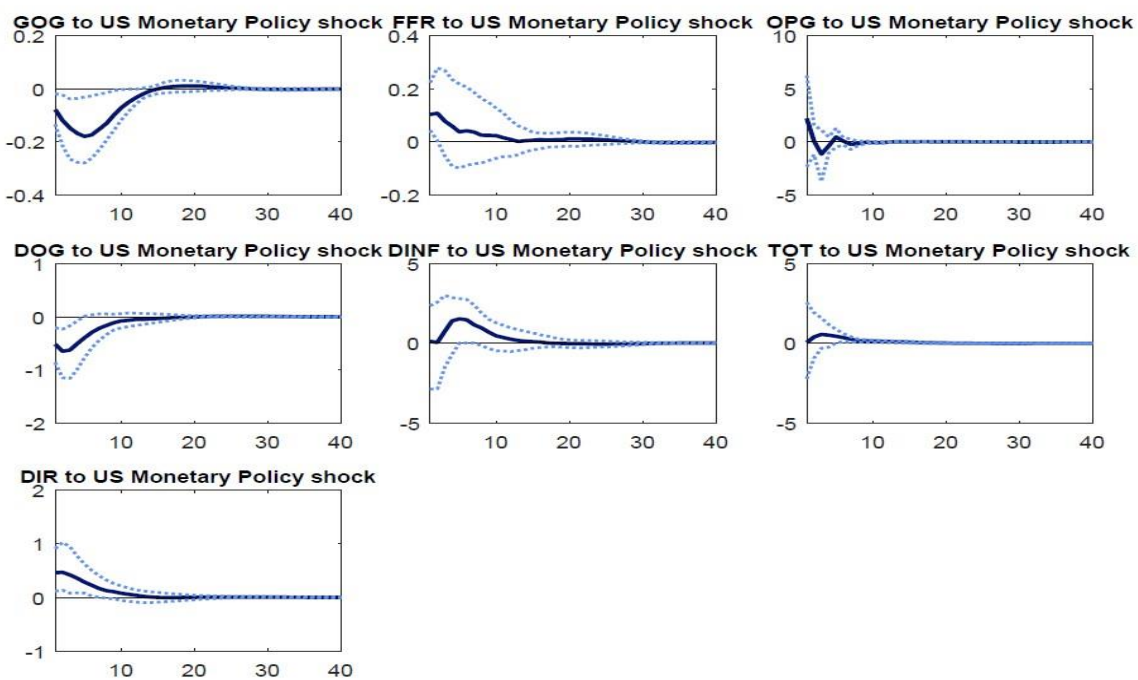

Figure 5: Impulse Responses to the US Monetary Policy Shock

A US monetary policy shock is a trigger for capital outflow from Nigeria. Substantial capital outflow in response to higher interest rate structure in the US can precipitate inflationary pressure in Nigeria via the exchange rate channel. The delay period in inflation's response to a US monetary policy shock may be attributable to investors possible cautious attitude or their inability to liquidate their current holdings of domestic financial assets immediately, owing to possible restrictions and maturities. Domestic interest rate responded quite positively to the tightening of monetary policy in the US. This is a plausible response in order to retain and attract capital flows while also stemming inflationary pressures.

\subsubsection{Oil Price Shock}

A major external shock that affect the world economy and particularly the oil-exporting small open economies is oil price shock. Impulse response functions as shown in figure 3 indicate that a unit shock to oil price growth elicit considerable decline in global output growth. Similarly, the response of the US monetary policy to a unit shock to oil price is rather aggressive and persistent. This is because, while global output growth declined by about 0.08 percent before reverting to steady state in the thirteenth quarter, the US monetary policy was eased by nearly 0.125 percent to accommodate the oil shock and it did not revert to steady state until around the twentieth quarter. This result suggests that the US Fed tends to respond dovishly and for a long time to developments in the global oil price. Oil price response to its own shock is sharp but short-lived, while terms-oftrade response to oil price growth shock is positive, substantial and short- 
lived; in the manner of oil price response to its own shock. It seems evident from this dynamic response, that there is no guarantee that a positive oil price response to an oil shock can be sustained beyond three quarters as shown in figure 6 .
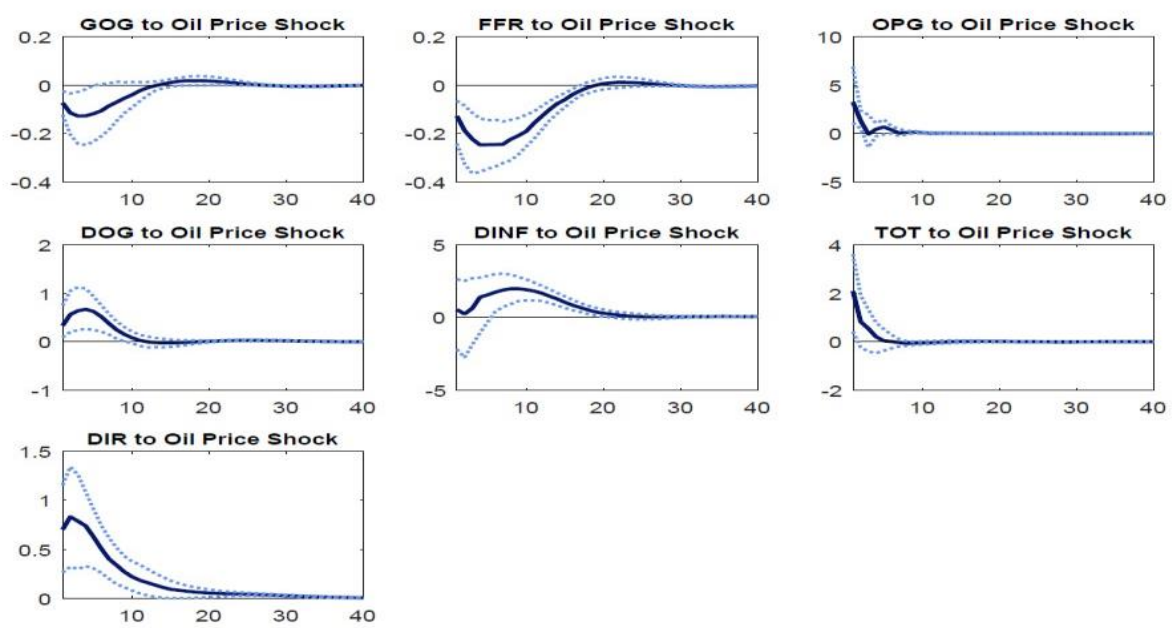

Figure 6: Impulse Responses to Oil Price Shock

Domestic output growth, a major business cycle variable, shows a mild but positive response to oil price growth shock and the response persisted for nearly ten quarters. The sluggish and unsteady positive response of domestic inflation to oil price shock grew to about 2 percent by the tenth quarter before finally dissipating after quarter 20 . The benign response of inflation to oil price shock may be attributed to the central bank's active monetary policy action to keep inflation within an implicit target, as can be observed from the sharp response of domestic interest rate to the oil price shock. Oil price shock also elicits a 0.75 percent tightening of the domestic monetary policy. Given oil price innovations, it is common for oil-exporting SOE central banks to tighten policy stance in order to contain inflation and ensure positive real interest rate.

\subsection{External Shocks and Domestic Business Cycle: A Robustness Analysis}

Given the impacts of the recent global financial crisis on small open economies, we conduct a simple robustness exercise by re-estimating the model for the pre-GFC period 1982Q2 - 2007Q4 and comparing the impulse responses. 


\subsubsection{Global Demand Shock}

The response of domestic output to the global demand shock in the two estimations are comparable in terms of magnitude but less persistent in the pre-GFC sample. The impulse generates about 0.5 percent responses under both estimations, but the effect lingered for longer in the full sample estimation. This suggests that the GFC may have contributed to the amplification of the persistence of the effect of the global demand shock in Nigeria. In addition, response pattern of interest rate following a global demand shock are similar under both estimations, indicating that there was no significant change in CBN's strategy for responding to global demand shocks pre and post the GFC. Overall, given that the global demand shock causes comparable magnitude of responses in domestic output growth and interest rate pre and post GFC, it can be inferred that macroeconomic risk associated with a negative demand shock are systematic or undiversifiable in nature.
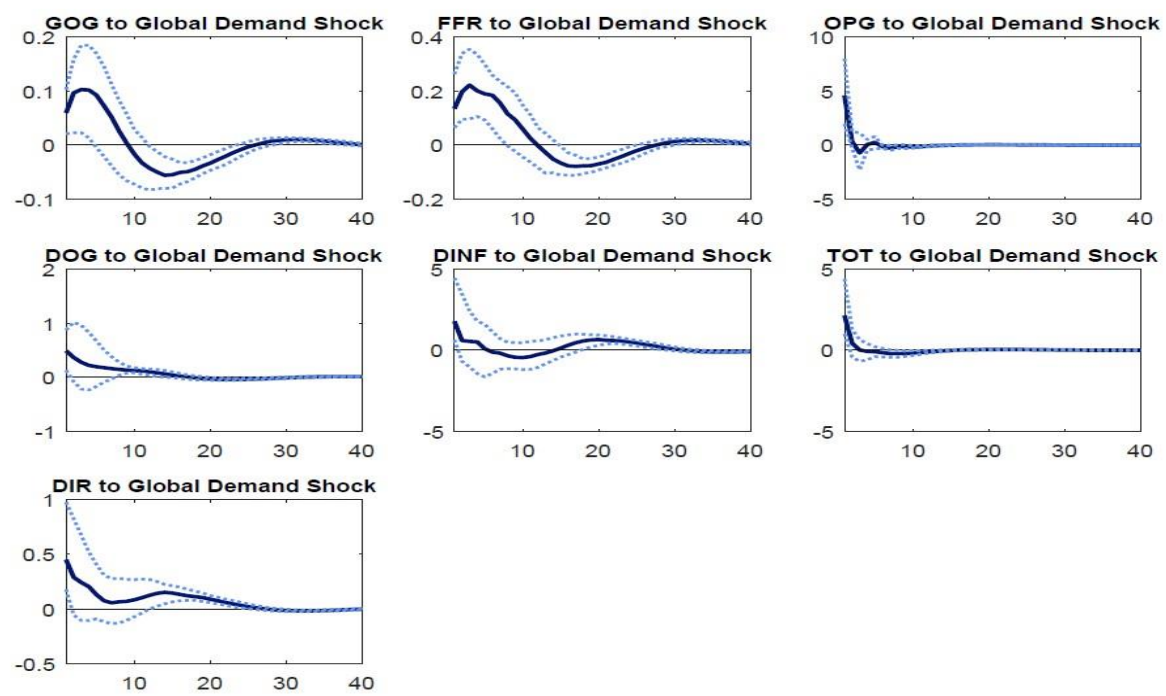

Figure 7: Impulse Responses to the Global Demand Shock (Pre-GFC)

Unlike the pronounced inflation volatility associated with the full sample estimation results, inflation volatility moderates in the current estimation results; suggesting that the global financial crisis contributes to higher inflationary response to global demand shock.

\subsubsection{US Monetary Policy Shock}

The domestic output growth shrank mildly and then returned to steady state in the eight quarter in response to a unit shock to the US monetary policy. On impact, the shock caused a temporary fall in inflation, but by 
the third quarter, inflation had risen significantly and remained persistent till the twenty fifth quarter. Domestic interest rate's response to a US monetary policy shock is positive and similar in magnitude to that under the baseline estimation but different in terms of persistence level.
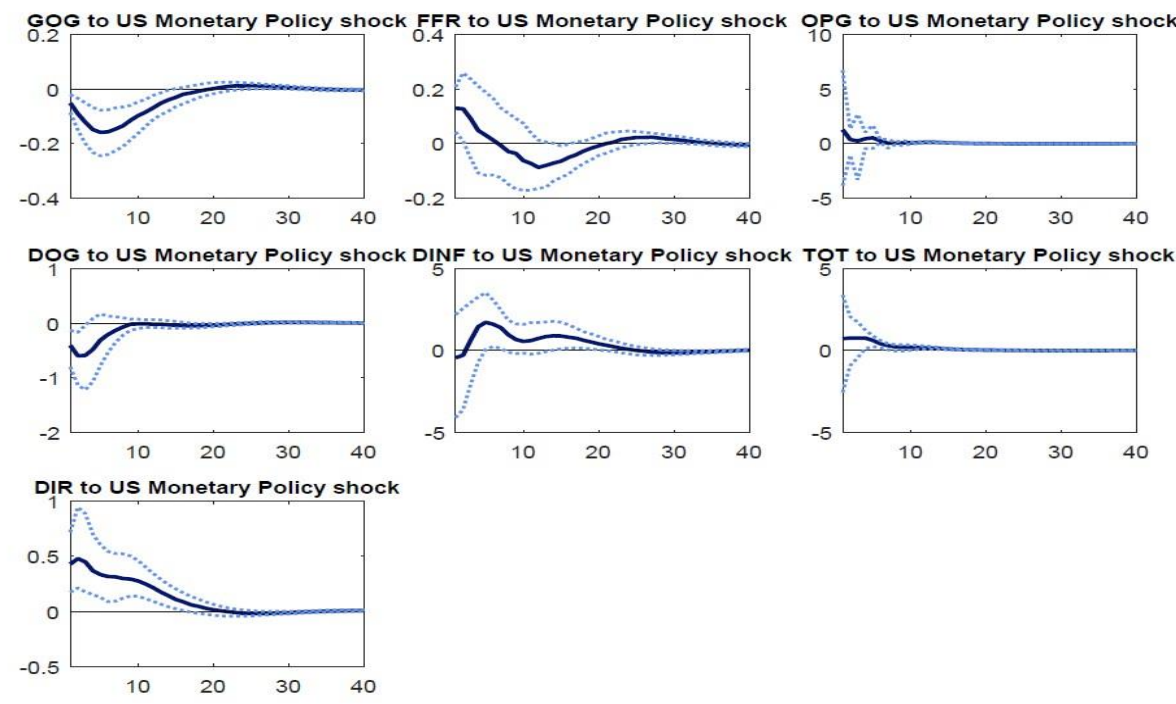

Figure 8: Impulse Responses to US Monetary Policy Shock (Pre-GFC)

The effect of the shock on domestic interest rate persists in the current estimation until the twentieth quarter compared to the previous estimation which dissipated quicker in the tenth quarter. The response of the termsof-trade to the shock is positive but subdued and died out in the tenth quarter.

\subsubsection{Oil Price Shock}

The effect of oil price shock on domestic variables is similar under both the full sample and sub-sample estimations, although with varying degrees of persistence. Whereas, the impact of the shock is more persistent on domestic output growth and inflation pre-crisis, the domestic interest rate response to oil price shock is more persistent in the model with the full sample. Intensity and persistence of oil price shock are essentially the same under both estimation samples for oil price and terms-of-trade. 

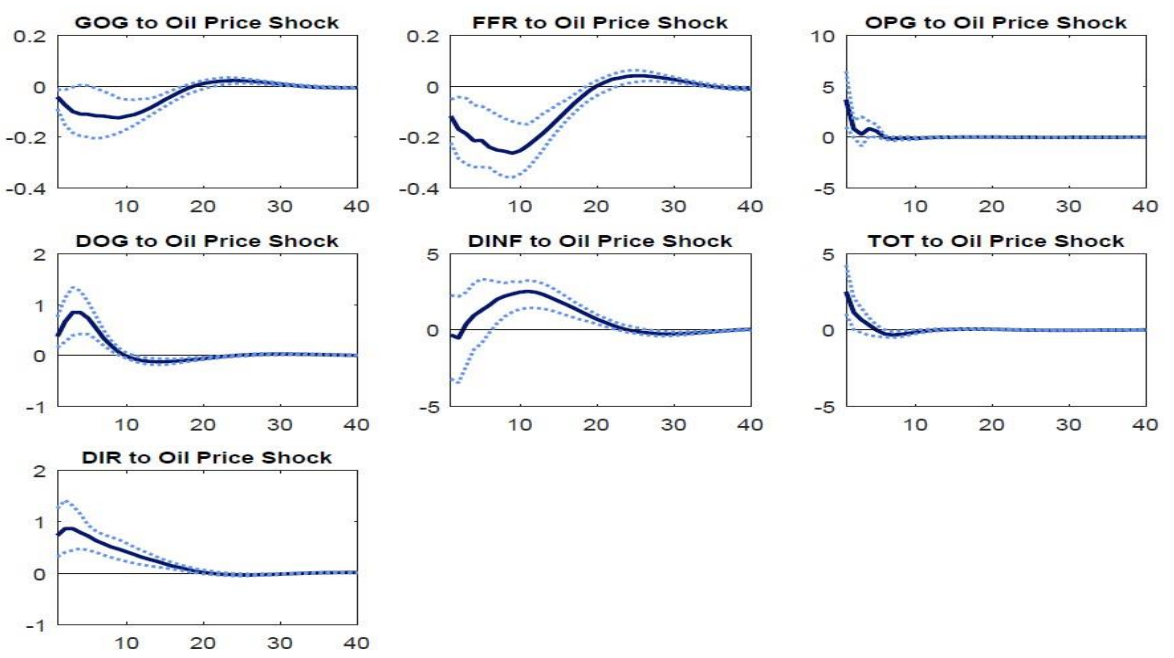

Figure 9: Impulse Responses to an Oil Price Shock (Pre-GFC)

As shown in figure 9, domestic inflation, following an agnostic identification, exhibit a temporary negative response on impact before reversing to positive territory in the third quarter. This initial negative inflation response to oil price shock is at variance with the small, volatile but positive response inflation exhibited in the full sample estimation. From this result, it may be inferred that in a crisis-free world, oil price shock pass-through to lower inflation may be more pronounced in Nigeria.

\subsection{Historical Decomposition of External Shocks}

Figures 10, 11, 12 and 13 reveal, respectively, the contributions of the three identified external shocks to the Nigerian business cycle fluctuations via the domestic output growth, the domestic inflation, the terms-of-trade and the domestic interest rate for the period 1982Q2 - 2016Q1. The historical contributions of the decomposed shocks are displayed in the upper panels of each figure, while a trend chart of the underlining domestic variables that these shocks drive are plotted in the lower panels of the referenced figures. 


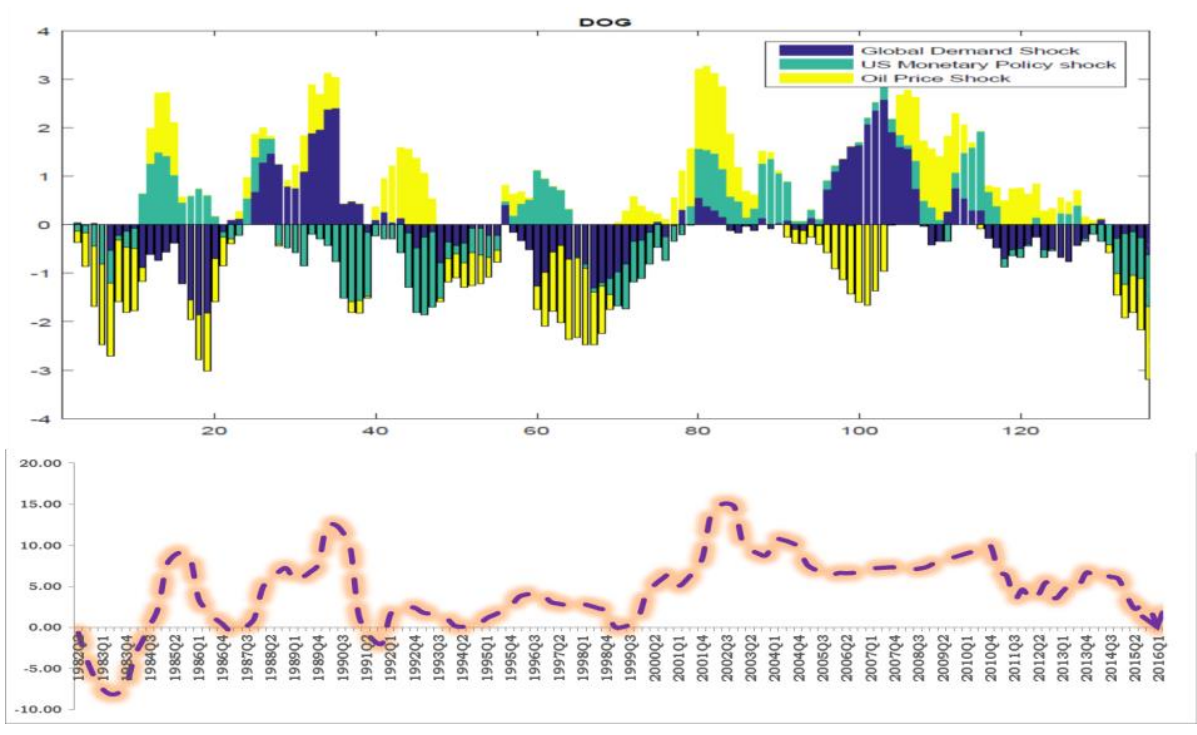

Figure 10: Historical Decomposition of Domestic Output Growth and Trend

The decomposition of external shocks in figure 7 shows that oil price and global demand shocks have comparable contributions to the domestic output growth movement in Nigeria. Positive oil price shocks are associated with high domestic output growth while negative oil price shocks are shown to correspond with moments of low, no and negative output growth. For instance, oil price shocks induced by the 1990 Gulf war and the 2011 terrorist attack in the US, respectively, resulted in higher output growth, while the negative oil price shocks between 2014Q1 2016Q1 are associated with deceleration in domestic output growth. This evidences Nigeria's high dependency on oil and exposure to vulnerability arising from oil price volatility.

The global demand shock and the Nigerian business cycle appear to comove, indicating that the country has its shares of the gains and pains of global economic growth and deceleration, respectively. Although, the impact of the US monetary policy shock on Nigeria's domestic output growth appear notable but is not as pronounced as the global demand and oil price shocks.

From figure 10, we observe that, for the most parts of the sample, whenever both oil price and the US interest rate shocks are positive, domestic output growth tends to gain momentum; while an episode of high global demand and high interest rate does not seem to provide any significant impetus for domestic economic growth. Our results also 
indicate that during the Gulf War of 1990, the simultaneous positive global demand and oil price shocks, together with a negative US interest rate shock contributes to higher domestic economic growth.

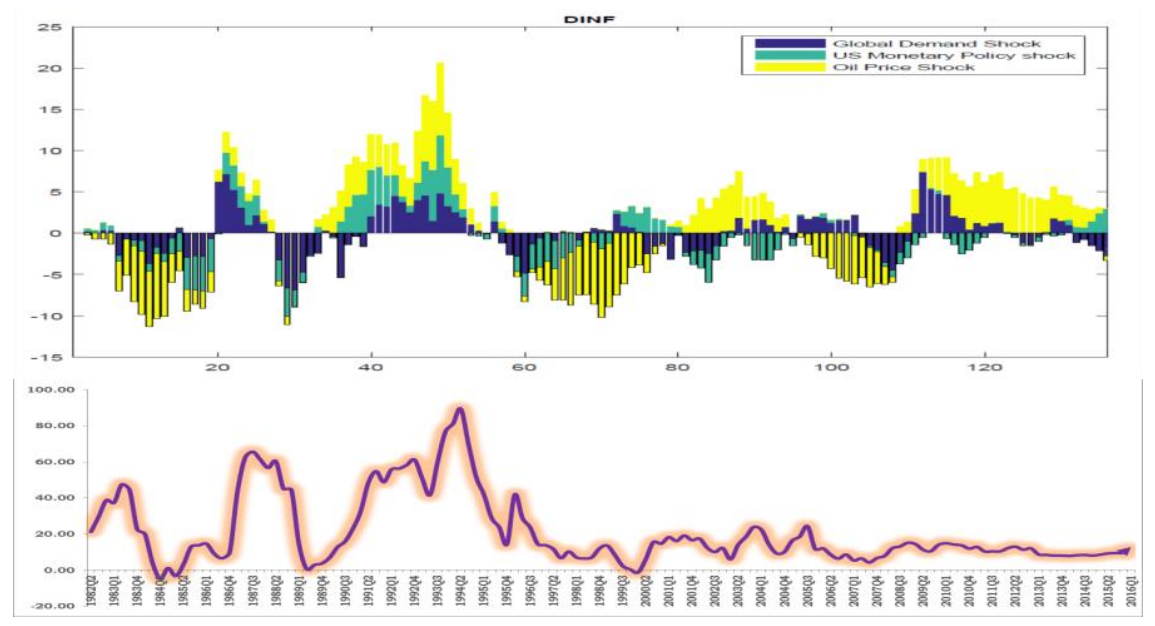

Figure 11: Historical Decomposition of Domestic Inflation and Trend

Figure 11 also reveals oil price shock as the key contributor to inflation dynamics in Nigeria. Between 1982 and 1999 when inflation volatility was most pronounced, oil price shocks is shown to co-move with domestic inflation trend. This persisted throughout the remaining parts of the sample, albeit, in a relatively low and stable inflation environment. A departure from this trend, however, ensued in 2015Q4, where negative oil price shock seems to drive inflation upward, mainly due to the foreign exchange crisis following the massive decline in oil earnings.

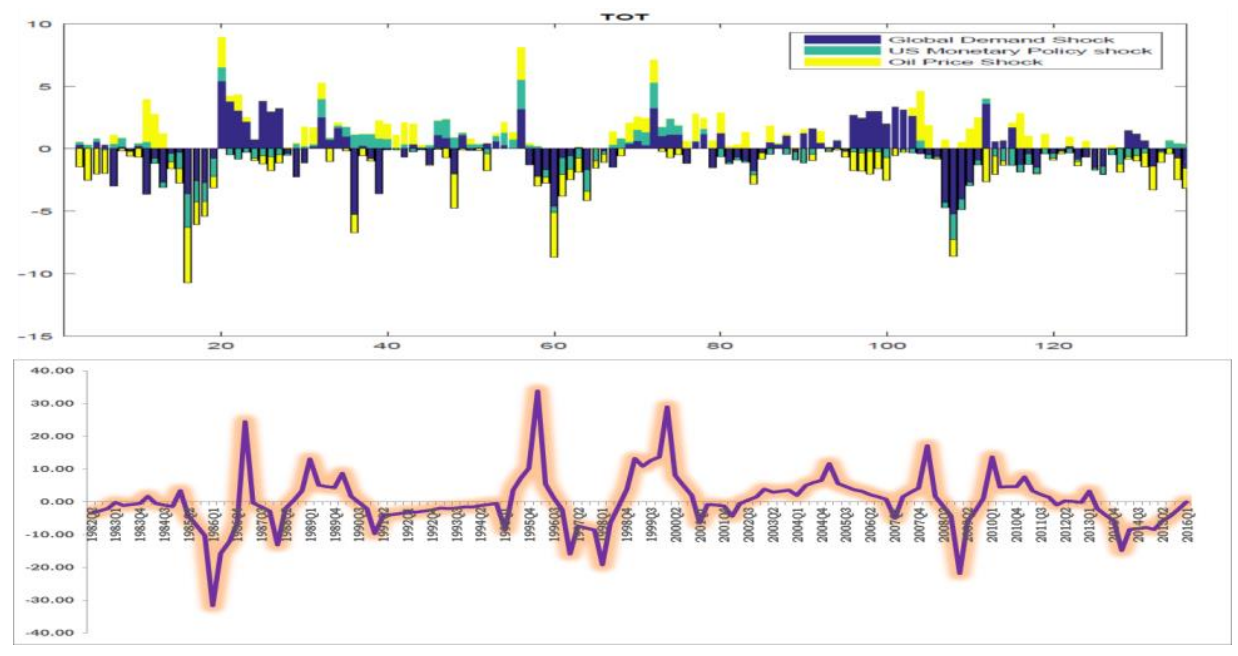

Figure 12: Historical Decomposition of Terms-of-trade and Trend 
In the decomposition of the shocks driving terms-of-trade as shown in figure 12, oil price and global demand shocks appear to be the leading contributors. The terms-of-trade is a mirror image of the oil price, as oil exports constitute the lion share of Nigeria's trade with the rest of the world. To reduce the influence of the oil component in the terms-of-trade, the non-oil component of the terms-of-trade must increase significantly.

The results in figure 10 reveal that the Central Bank of Nigeria, in setting the interest rate, tends to pay attention to oil price movement, as episodes of positive oil price shocks are associated with tight monetary policy. Higher oil price and earnings provides impetus for increased government expenditure and raises the concern about inflation.

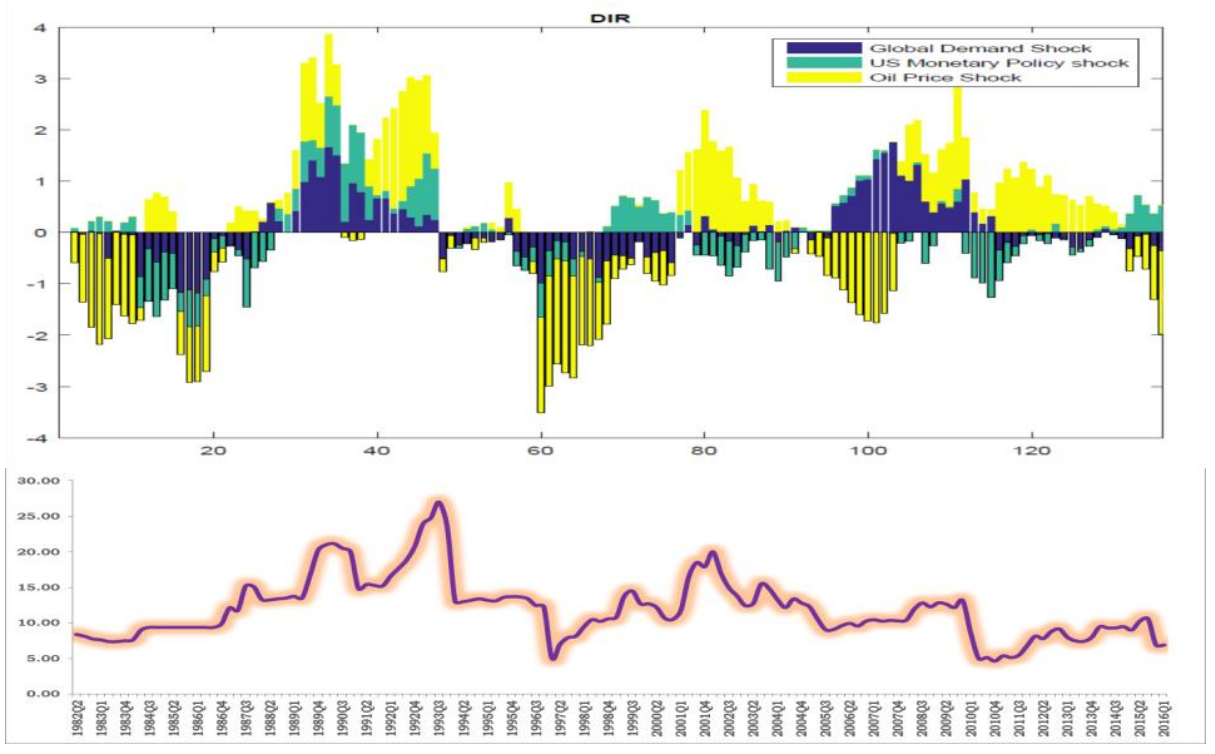

Figure 13: Historical Decomposition of Domestic Interest Rate and Trend

At such times, the banking system experiences excess money supply, which tends to encourage increased demand for imports leading to foreign exchange market pressure. This causes an interest rate hike by the central bank in order to contain inflation.

\subsection{Conclusion and Policy Recommendations}

We employ a sign-restricted structural vector autoregressive (SVAR) model to examine the role of external shocks in the evolution of business cycle in Nigeria. Our identification structure reflects findings by Mumtaz and Surico (2009), Kilian and Lewis (2011), Olayeni (2009) and Allegret 
and Benkhodja (2015). Three external shocks were identified in a seven variable SVAR model.

Our results indicate that global demand and oil price shocks dominate as drivers of the Nigerian business cycle. Particularly, the effect of the global demand shock on important business cycle variables is revealed to be most fundamental. Global demand shock is most profound on domestic output and inflation while oil price shock exerts the most influence on domestic interest rate and the terms-of-trade. Our robustness exercise indicates that the macroeconomic risk associated with global demand shock is systematic, given that its impact remains visible with or without taking the GFC into consideration. Inflation in Nigeria is most sensitive to global demand shock, but most driven historically by oil price shock. The GFC is shown to have amplified the sensitivity of domestic inflation to the global demand shock, thus, resulting to higher inflation volatility.

The central bank, beyond the considerations for oil, should pay greater attention to global demand dynamics in order to respond more strategically to contain inflation volatility arising from global demand shocks. This is particularly crucial, as our findings suggest that monetary policy response to the global demand shock was essentially the same before and during the crisis. In addition, given the strong and pervasive impact of the global demand shock on domestic output growth in Nigeria, appropriate policy measures are required to ensure the gains of positive global demand shocks are maximised and dynamic responses to minimise the adverse effects of negative global demand shocks on the economy. To address oil-exporting SOEs vulnerability to oil shocks, the fraction of crude oil exports in their terms-of-trade must decrease while that of the non-oil exports must improve progressively through sustained economic diversification and industrialisation strategy.

\section{References}

Adebiyi, A., \& Mordi, C. N. (2012). A dynamic stochastic general equilibrium (DSGE) model of oil price shocks and exchange rate pass-through to domestic inflation in Nigeria (No. 3715). EcoMod.

Adolfson, M., Laséen, S., Christiano, L., Trabandt, M., \& Walentin, K. (2013). Ramses ii-model description. Sveriges Riksbank Occasional Paper Series, 12, 1009. 
Akpan, E. O. (2009, March). Oil price shocks and Nigeria's Macroeconomy. In A Paper Presented at the Annual Conference of CSAE Conference, Economic Development in Africa, March (pp. 22-24).

Alege, P. O. (2012). A Business Cycle Model for Nigeria. CBN Journal of Applied Statistics, 3(1), 85-115.

Allegret, J. P., \& Benkhodja, M. T. (2015). External shocks and monetary policy in an oil exporting economy (Algeria). Journal of Policy Modeling, 37(4), 652-667.

Baumeister, C., \& Peersman, G. (2013). The role of time-varying price elasticities in accounting for volatility changes in the crude oil market. Journal of Applied Econometrics, 28(7), 1087-1109.

Bernanke, B. S., Gertler, M., Watson, M., Sims, C. A., \& Friedman, B. M. (1997). Systematic monetary policy and the effects of oil price shocks. Brookings papers on economic activity, 1997(1), 91-157.

Bjørnland, H. C., \& Thorsrud, L. A. (2014). Applied time series for macroeconomics. Gyldendal akademisk.

Broda, C. M., \& Tille, C. (2003). Coping with terms-of-trade shocks in developing countries. Current issues in Economics and Finance, 9(11).

Calvo, G. A., Leiderman, L., \& Reinhart, C. M. (1993). Capital inflows and real exchange rate appreciation in Latin America: the role of external factors. Staff Papers, 40(1), 108-151.

Canova, F. (2005). The transmission of US shocks to Latin America. Journal of Applied econometrics, 20(2), 229-251.

Canova, F. (2007). Methods for Applied Macroeconomic Research (Vol. 13). Princeton University Press.

Canova, F., \& De Nicolo, G. (2002). Monetary disturbances matter for business fluctuations in the G-7. Journal of Monetary Economics, 49(6), 1131-1159.

Carlstrom, C. T., \& Fuerst, T. S. (2006). Oil prices, monetary policy, and counterfactual experiments. Journal of Money, Credit and Banking, 38(7), 1945-1958. https://www.jstor.org/stable/3838971 
Cashin, P., \& Sosa, S. (2013). Macroeconomic fluctuations in the Eastern Caribbean: The role of climatic and external shocks. The Journal of International Trade \& Economic Development, 22(5), 729-748.

Christiano, L. J., Eichenbaum, M., \& Evans, C. L. (1998). Monetary policy shocks: what have we learned and to what end? (No. w6400). National bureau of economic research.

Christopher, A., \& Bedekt, G. (2006). Monetary policy and oil price Surges in Nigeria. Paper presented at centre for the study of African economics, Oxford university.

Clarida, R., \& Gali, J. (1994, December). Sources of real exchange-rate fluctuations: How important are nominal shocks? In CarnegieRochester conference series on public policy (Vol. 41, pp. 1-56). North-Holland.

Dedola, L., \& Neri, S. (2007). What does a technology shock do? A VAR analysis with model-based sign restrictions. Journal of Monetary Economics, 54(2), 512-549.

Dungey, M., \& Pagan, A. (2000). A structural VAR model of the Australian economy. Economic record,76(235), 321-342. Economic record, 76(235), 321-342.

Dungey, M. H. (2002). International Shocks and the Role of Domestic Policy in Australia. Australian Journal of Labour Economics, 5(2), 143-163.

Faust, J. (1998, December). The robustness of identified VAR conclusions about money. In Carnegie-Rochester Conference Series on Public Policy (Vol. 49, pp. 207-244). North-Holland.

Fernández-Villaverde, J., \& Rubio-Ramírez, J. (2010). Macroeconomics and volatility: Data, models, and estimation (No. w16618). National Bureau of Economic Research.

Fry, R., \& Pagan, A. (2011). Sign restrictions in structural vector autoregressions: A critical review. Journal of Economic Literature, 49(4), 938-60.

Fujita, S. (2018). Declining labor turnover and turbulence. Journal of Monetary Economics, 99, 1-19. 
Gali, J., \& Monacelli, T. (2005). Monetary policy and exchange rate volatility in a small open economy. The Review of Economic Studies, 72(3), 707-734.

Genberg, H. (2005). External Shocks, Transmission Mechanisms, and Deflation in Asia (No. 187). BIS Working Paper.

Gimet, C. (2011). The vulnerability of Asean +3 countries to international financial crises. Review of International Economics, 19(5), 894-908.

Hamilton, J. D., \& Herrera, A. M. (2004). Comment: oil shocks and aggregate macroeconomic behavior: the role of monetary policy. Journal of Money, Credit, and Banking, 36(2), 265-286. https://www.jstor.org/stable/3839020

Houssa, R., Mohimont, J., \& Otrok, C. (2015). Sources of business cycles in a low income country. Pacific Economic Review, 20(1), 125-148.

Huang, Y., \& Guo, F. (2006). Is currency union a feasible option in East Asia?: A multivariate structural VAR approach. Research in international business and finance, 20(1), 77-94.

Huh, H. S., \& Kwon, W. S. (2015). Sources of Fluctuations in the Real Exchange Rates and Trade Balances of the G-7: A Sign Restriction VAR Approach. Review of International Economics, 23(4), 715737.

Inoue, A., \& Kilian, L. (2013). Inference on impulse response functions in structural VAR models. Journal of Econometrics, 177(1), 1-13.

Jääskelä, J. P., \& Smith, P. (2013). Terms of trade shocks: What are they and what do they do? Economic Record, 89(285), 145-159.

Karagedikli, O., \& Price, G. (2012, June). Identifying terms of trade shocks and their transmission to the New Zealand economy. In New Zealand Association of Economists Conference, Wellington: New Zealand Association of Economists.

Kilian, L. (2008). The economic effects of energy price shocks. Journal of Economic Literature, 46(4), 871-909.

Kilian, L. (2013). Structural vector autoregressions. In Handbook of research methods and applications in empirical macroeconomics. Edward Elgar Publishing. 
Kilian, L., \& Lewis, L. T. (2011). Does the Fed respond to oil price shocks?. The Economic Journal, 121(555), 1047-1072.

Kilian, L., \& Murphy, D. P. (2012). Why agnostic sign restrictions are not enough: understanding the dynamics of oil market VAR models. Journal of the European Economic Association, 10(5), 1166-1188.

Kim, H. (2013). Generalized impulse response analysis: General or Extreme?. EconoQuantum, 10(2), 136-141.

Kim, S. (2001). International transmission of US monetary policy shocks: Evidence from VAR's. Journal of Monetary Economics, 48(2), 339372.

Liu, P. (2010). The effects of international shocks on Australia's business cycle. Economic Record, 86(275), 486-503.

Lütkepohl, H. (2013). Identifying Structural Vector Autoregressions Via Changes in Volatility 2 This article was written while the author was a Bundesbank Professor at the Freie Universität Berlin. An earlier version of the paper was published as DIW Discussion Paper, 169203.

Maćkowiak, B. (2007). External shocks, US monetary policy and macroeconomic fluctuations in emerging markets. Journal of monetary economics, 54(8), 2512-2520.

Mendoza, E. G. (1995). The terms of trade, the real exchange rate, and economic fluctuations. International Economic Review, 36(1), 101137. https://www.jstor.org/stable/2527429

Monacelli, T. (2005). Monetary policy in a low pass-through environment. Journal of Money, Credit and Banking, 37(6), 10471066. https://www.jstor.org/stable/3839027

Mountford, A., \& Uhlig, H. (2009). What are the effects of fiscal policy shocks?. Journal of applied econometrics, 24(6), 960-992.

Mumtaz, H., \& Surico, P. (2009). The transmission of international shocks: a factor-augmented VAR approach. Journal of Money, Credit and Banking, 41, 71-100.

Nason, J. M., \& Cogley, T. (1994). Testing the implications of long-run neutrality for monetary business cycle models. Journal of Applied 
70 External Shocks and Business Cycle Fluctuations in Oil-exporting Small Open Economies: The Case of Nigeria

Econometrics, 9(S1), S37-S70.

https://www.jstor.org/stable/2285223

Ng, T. H. (2002). Should the Southeast Asian countries form a currency union?. The Developing Economies, 40(2), 113-134.

Nimark, K. (2007). A structural model of Australia as a small open economy. Reserve Bank of Australia. Research Discussion Paper 2007001. http://www.rba.gov.au/rdp/RDP2007001.pdf.

Olayeni, O. R. (2009). A small open economy model for Nigeria: a BVAR-DSGE approach. Available at SSRN 1432802.

Olomola, P. A., \& Adejumo, A. V. (2006). Oil price shock and macroeconomic activities in Nigeria. International Research Journal of Finance and Economics, 3(1), 28-34.

Omisakin, D., \& Olusegun, A. (2008). Oil price shocks and the Nigerian economy: a forecast error variance decomposition analysis. Journal of Economic Theory, 2(4), 124-130.

Pappa, E. (2009). The effects of fiscal shocks on employment and the real wage. International Economic Review, 50(1), 217-244.

Olomola, P. A., \& Adejumo, A. V. (2006). Oil price shock and macroeconomic activities in Nigeria. International Research Journal of Finance and Economics, 3(1), 28-34.

Rafiq, M. S. (2011). Sources of economic fluctuations in oil-exporting economies: implications for choice of exchange rate regimes. International Journal of Finance \& Economics, 16(1), 7091.

Sariola, M. (2015). What drives business cycles in Sweden? A sign restriction structural VAR approach. Discussion Papers, 1, 2015.

Sato, K., Zhang, Z., \& McAleer, M. (2011). Identifying shocks in regionally integrated East Asian economies with structural VAR and block exogeneity. Mathematics and Computers in Simulation, 81(7), 1353-1364.

Scholl, A., \& Uhlig, H. (2008). New evidence on the puzzles: Results from agnostic identification on monetary policy and exchange rates. Journal of International Economics, 76(1), 1-13. 
Schorfheide, F. (2000). Loss function-based evaluation of DSGE models. Journal of Applied Econometrics, 15(6), 645-670.

Silva, M. E. A. (2011, September). Commodity price shocks and business cycles in emerging economies. In $33^{\circ}$ Meeting of the Brazilian Econometric Society.

Sims, C. A. (1980). Macroeconomics and reality. Econometrica: journal of the Econometric Society, 1-48.

Uhlig, H. (2005). What are the effects of monetary policy on output? Results from an agnostic identification procedure. Journal of Monetary Economics, 52(2), 381-419.

Kilishi, A. A. (2010). Oil price shocks and the Nigeria economy: A variance autoregressive (VAR) model. International Journal of Business and Management, 5(8).

Utlaut, J., \& Van Roye, B. (2010). The effects of external shocks to business cycles in emerging Asia: A Bayesian-VAR approach. Institute for the World Economy. 